\title{
RANCANGAN SISTEM INFORMASI SIMPAN PINJAM PADA KOPERASI GURU DAN PEGAWAI SMP NEGERI 45 JAKARTA
}

\author{
Angga Aditya Permana \\ Universitas Muhammadiyah Tangerang / Fakultas Teknik, \\ Program Studi Informatika \\ Jl. Perintis Kemerdekaan 1/33 Cikokol Kota Tangerang TLP. 55793251, 55772949, 55793802, 55736926 \\ e-mail: anggaumt@gmail.com
}

\begin{abstract}
ABSTRAK
Perkembangan komputer sangatlah penting terhadap perkembangan suatu perusahaan, khususnya yang bergerak dalam bidang koperasi simpan pinjam. Pemberian pelayanan yang maksimal kepada para anggotanya merupakan salah satu misi yang dijalankan koperasi ini dengan tujuan meningkatkan kesejahteraan para anggotanya. Sistem informasi yang baik diperlukan untuk membantu dan mengawasi kegiatan simpan pinjam, sehingga dapat mengikuti perkembangan usaha yang sedang berkembang. Koperasi Guru dan Pegawai SMP Negeri 45 Jakarta memerlukan suatu perancangan sistem informasi yang akan membantu karyawannya dalam menangani administrasi simpan pinjam. Pada penelitian ini, suatu sistem komputerisasi simpan pinjam pada Koperasi Guru dan Pegawai SMP Negeri 45 Jakarta yang sesuai berhasil dibuat dan dirancang untuk mendukung berkembangnya koperasi tersebut.
\end{abstract}

Kata Kunci: Koperasi, Simpan Pinjam, Sistem Simpan Pinjam

\section{PENDAHULUAN}

Informasi berperan penting dalam semua aspek kehidupan terutama bagi mereka yang menekuni dunia bisnis. Kemajuan teknologi khususnya komputer menjadikan mereka yang bergerak di dunia bisnis perlu mencermati peluang yang mereka miliki karena komputer merupakan penunjang utama bagi sistem informasi di era modern ini, komputer sebagai sarana pengolah data membantu manusia untuk dapat menghasilkan informasi yang dibutuhkan dengan cepat, tepat dan akurat. Pemakaian sistem informasi yang terkomputerisasi sebagai alat pengolah data dapat dikatakan sebagai solusi terbaik untuk saat ini, karena dapat meningkatkan kecepatan pekerjaan sehingga dicapai efisiensi tenaga dan waktu dalam mengolah data.

Sistem informasi akan mempermudah suatu perusahaan atau instansi didalam melakukan proses pengolahan data dengan pengambilan keputusan yang tepat bagi pihak manajemen. Karena itu, sistem informasi memegang peranan penting didalam perkembangan suatu perusahaan atau instansi. Dengan adanya sistem informasi yang baik, maka perusahaan atau instansi akan memperoleh kemudahan untuk mempercepat tugas dan pekerjaan termasuk pada koperasi.

Sistem yang sedang berjalan pada koperasi Guru dan Pegawai SMP Negeri 45
Jakarta belum terorganisir dengan baik, masih ada beberapa dokumen yang masih disimpan secara manual. Hal ini sering menimbulkan kesalahan, keterlambatan dan kekurangan efektivitas kerja.

Permasalahan-permasalahan yang terjadi pada Koperasi Guru dan Pegawai SMP Negeri 45 Jakarta saat ini, dapat diatasi dengan menerapkan sistem yang terkomputerisasi yang akan membuat transaksi menjadi efektif dan efisien. Oleh karena itu, sistem informasi simpan pinjam pada Koperasi Guru dan Pegawai SMP Negeri 45 Jakarta perlu dirancang dengan baik, sehingga pengontrolan data yang masuk dan keluar lebih mudah, kesalahan mengenai pencatatan dan penghitungan dapat diminimalisir, penyimpanan data yang lebih aman, pencarian data yang lebih mudah dan laporan-laporan simpan pinjam dapat disajikan dengan cepat dan akurat.

\section{TINJAUAN PUSTAKA}

\section{Sistem}

Sistem adalah suatu kumpulan atau himpunan dari unsur, komponen atau variabel yang terorganisasi, saling berinteraksi, saling tergantung satu sama lain dan terpadu [1]. Berdasarkan Kamus Besar Bahasa Indonesia terdapat dua pengertian sistem [2], yaitu: 
a. sistem adalah perangkat unsur yang secara teratur saling berkaitan sehingga membentuk suatu totalitas.

b. susunan yang teraturdari pandangan, teori, asas dan sebagainya.

Suatu sistem mempunyai karakteristik atau sifat-sifat tertentu [3], yaitu :

a. Komponen Sistem

Sistem adalah suatu kesatuan yang dibangun oleh beberapa komponen yang saling berkaitan satu sama lain. Secara garis besar, komponen yang dimiliki oleh suatu sistem adalah sama. Komponenkomponen sistem tersebut dapat berupa suatu subsistem atau bagian-bagian dari sistem. Setiap subsistem mempunyai sifatsifat dari sistem untuk menjalankan suatu fungsi tertentu dan mempengaruhi proses sistem secara keseluruhan. Elemen-elemen yang lebih kecil yang disebut subsistem, misalkan sistem komputer terdiri dari subsistem perangkat keras, perangkat lunak dan manusia.Elemen-elemen yang lebih besar yang disebut supra sistem. Misalkan bila perangkat keras adalah sistem yang memiliki subsistem CPU, perangkat I/O dan memori, maka supra sistem perangkat keras adalah sistem komputer.

b. Batas Sistem (Boundary)

Suatu sistem memiliki sebuah daerah yang memberi batasan antara suatu sistem dengan sistem lainnya atau suatu sistem dengan lingkungan luarnya yang disebut dengan batas sistem atau boundary. Batas sistem menunjukkan ruang lingkup dari suatu sistem,sehingga sistem tersebut dipandang sebagai suatu kesatuan.

c. Lingkungan Luar Sistem (Environment) Lingkungan luar sistem adalah segala sesuatu yang berada di luar batas dari sistem tetapi tetap mempengaruhi operasi sistem. Lingkungan luar sistem dapat bersifat menguntungkan dan dapat juga bersifat merugikan. Lingkungan luar yang mengutungkan harus tetap dijaga dan dipelihara, sedangkan lingkungan luar yang merugikan harus ditahan dan dikendalikan, jika tidak akan mengganggu kelangsungan hidup dari sistem.

d. Penghubung Sistem (Interface)

Penghubung sistem adalah media perantara antar subsistem (elemen-elemen yang lebih kecil). Melalui penghubung tersebut, sumber-sumber daya dapat mengalir dari satu subsistem ke subsistem lainnya.
Dengan penghubung satu subsistem dapat berinteraksi dengan subsistem yang lainnya membentuk satu kesatuan.

e. Masukan(Input)

Masukan adalah energi yang dimasukkan ke dalam sistem. Masukan dapat berupa maintenance input dan sinyal input. Maintenance input adalah energi yang dimasukkan supaya sistem tersebut dapat beroperasi. Sinyal input adalah energi yang diproses untuk didapatkan keluaran.

f. Keluaran (Output)

Keluaran adalah hasil dari energi yang diolah dan diklasifikasikan menjadi keluaran yang berguna dan sisa pembuangan. Keluaran dapat merupakan masukan untuk subsistem yang lain atau kepada supra sistem.

g. Pengolahan Sistem (Process)

Suatu sistem dapat mempunyai suatu bagian pengolah atau sistem itu sendiri sebagai pengolahnya. Pengolah yang akan merubah masukan menjadi keluaran.

h. Sasaran (Objective) atau Tujuan (Goal) Sistem

Suatu sistem pasti mempunyai tujuan atau sasaran. Kalau suatu sistem tidak mempunyai sasaran, maka operasi sistem tidak akan ada gunanya. Sasaran dari sistem sangat menentukan sekali masukan yang dibutuhkan sistem dan keluaran yang akan dihasilkan sistem. Suatu sistem dikatakan berhasil bila mengenai sasaran atau tujuannya.

\section{Informasi}

Informasi adalah data yang telah diklasifikasikan atau diolah atau diinterpretasikan untuk digunakan dalam proses pengambilan keputusan. Teori informasi lebih tepat disebut sebagai teori matematika komunikasi yang memberikan pandangan yang berguna bagi sistem inforasi, di mana konsep usia informasi menunjukkan hubungan interval informasi, jenis data dan penundaan pengolahan dalam menentukan usia informasi [1].

Berdasarkan Kamus Besar Bahasa Indonesia, terdapat tiga pengertian informasi [2], yaitu:

a. penerangan.

b. keterangan.pemberitahuan.kabar atau berita tentang sesuatu.

c. lingkungan keseluruhan makna yang menunjang amanat yang terlihat di dalam bagian amanat-amanat itu. 
berikut:

Informasi memiliki karakteristik sebagai

a. Memiliki nilai (benar atau salah), berhubungan dengan kenyataan atau tidak.

Bila informasi salah tetapi penerima mempercayainya maka sama seperti informasi yang benar.

b. Baru bagi penerima informasi memperbaharui atau memberikan tambahan informasi yang telah ada.

c. Korektif terhadap masalah yang salah.

d. Penegas, mempertegas informasi yang ada.

\section{Sistem Informasi}

Sistem informasi adalah suatu sistem di dalam suatu organisasi yang mempertemukan kebutuhan pengolahan transaksi harian yang mendukung fungsi operasi organisasi yang bersifat manajerial dengan kegiatan strategi dari suatu organisasi untuk dapat menyediakan laporan-laporan yang diperlukan oleh pihak luar tertentu [1]. Sistem informasi adalah suatu kegiatan dari prosedur-prosedur yang diorganisasikan, bilamana dieksekusi akan menyediakan informasi untuk mendukung pengambilan keputusan dan pengendalian di dalam organisasi [3]. Sistem informasi juga merupakan suatu pengumpulan data yang terorganisasi beserta tatacara penggunaannya yang mencakup lebih jauh daripada sekadar penyajian. Keberhasilan suatu sistem informasi tergantung pada keserasian dan mutu data, pengorganisasian data dan tata cara penggunaannya [4].

Sistem informasi terdiri dari komponenkomponen yang disebut blok bangunan (building block), yang terdiri dari komponen input, komponen model, komponen output, komponen teknologi, komponen hardware, komponen software, komponen basis data, dan komponen kontrol. Semua komponen tersebut saling berinteraksi satu dengan yang lain membentuk suatu kesatuan untuk mencapai sasaran.

\section{Koperasi dan Koperasi Simpan Pinjam}

Koperasi adalah perserikatan yang bertujuan memenuhi keperluan kebendaan anggotanya dengan cara menjual barangbarang kebutuhan dengan harga murah (tidak bermaksud mencari untung) Koperasi simpan pinjam adalah koperasi yang khusus bertujuan melayani atau mewajibkan para anggotanya untuk menabung, di samping dapat memberikan pinjaman kepada para anggotanya [2].
Berdasarkan Kamus Besar Bahasa Indonesia, koperasi adalah perserikatan yang bertujuan memenuhi keperluan kebendaan anggotanya dengan cara menjual barang-barang kebutuhan dengan harga murah (tidak bermaksud mencari untung). Sedangkan pengertian koperasi simpan pinjam adalah koperasi yang khusus bertujuan melayani atau mewajibkan para anggotanya untuk menabung, di samping dapat memberikan pinjaman kepada para anggotanya.

\section{Program}

Program adalah algoritma yang ditulis dalam bahasa komputer sedangkan bahasa komputer yang digunakan untuk menulis program dinamakan bahasa pemrograman, orang yang membuat program disebut pemrogram, kegiatan merancang dan menulis program disebut pemrograman dan aktivitas menulis kode program disebut coding [5].

\section{METODE PENELITIAN}

Pada penelitian ini dilakukan peninjauan lokasi untuk mendapatkan data yang dibutuhkan. Hal pertama adalah mendatangi tempat penelitian untuk mengamati situasi yang tergambar di dalam Koperasi Guru dan Pegawai SMP Negeri 45 Jakarta, sistem yang berjalan dan wawancara dengan beberapa petugas koperasi yang berwenang serta pengguna koperasi.

Metodologi merupakan suatu unsur mutlak yang harus ada dalam penelitian dan pengembangan ilmu pengetahuan. Metode ini membagi kegiatannya dalam tiga tahap, yaitu tahap analisa masalah dan studi kelayakan, analisa sistem, perancangan sistem.

\section{Tahap Analisa Masalah dan Studi Kelayakan}

Merupakan kegiatan mengidentifikasi masalah-masalah yang terjadi kemudian menyelesaikannya melalui suatu pengembangan sistem, tahap ini dilakukan dengan cara:

\section{a. Wawancara}

Wawancara dilakukan untuk mengetahui masalah yang timbul dan yang dialami langsung oleh bagian-bagian yang bersangkutan. Dalam kegiatan ini diajukan pertanyaan lisan dalam usaha untuk melengkapi data-data yang akan diperoleh. Wawancara dilakukan pada bagianbagian yang terkait dengan sistem simpan pinjam.

b. Observasi

Observasi adalah metode pengumpulan data dengan cara melihat obyek penelitian 
secara langsung ke lapangan atau lokasi penelitian dalam jangka waktu tertentu.

c. Studi Kepustakaan

Penulisan dilakukan dengan cara menyimpulkan dari data-data yang terdapat dari buku-buku yang menjadi referensi menyangkut sistem simpan pinjam, diktat atau catatan perkuliahan maupun buku-buku lainnya yang berhubungan dengan penelitian ini.

d. Studi Dokumentasi

Merupakan metode-metode pengumpulan data melalui arsip-arsip serta dokumendokumen yang terkait dengan sistem simpan pinjam pada koperasi.

Tahap Analisa Sistem

Kegiatan yang dilakukan pada tahap ini adalah :

a. Menganalisa sistem yang ada, yaitu memahami proses bisnis sistem yang sedang berjalan guna mengidentifikasikan permasalahan-permasalahan yang ada.

b. Analisa dokumen, yaitu menspesifikasikan masukan yang digunakan, database yang ada, proses yang dilakukan dan keluaran yang dihasilkan, guna memahami kebutuhan akan dokumen-dokumen baru.

Pada penelitian ini digunakan beberapa diagram Unified Modelling Language (UML) sebagai alat bantu dalam menganalisa sistem untuk mendeskripsikan proses bisnis sistem yang sedang berjalan serta mendeskripsi konsep sistem baru yang akan dikembangkan dimana sistem baru tersebut tentunya dapat memberikan solusi-solusi dari permasalahan yang ada serta memenuhi kebutuhan sistem. Beberapa diagram tersebut adalah :

a. Activity Diagram

Diagram yang menggambarkan alur kerja sebuah proses bisnis dan urutan aktivitas / kegiatan-kegiatan didalam suatu proses.

b. Use Case Diagram

Diagram yang menggambarkan kebutuhan sistem dari sudut pandang user atau dilihat menurut pandangan orang yang berada diluar sistem.

c. Use Case Description.

Use Case Description digunakan untuk mendeskripsikan secara rinci mengenai Use Case Diagram.

\section{Tahap Perancangan}

Tahap perancangan sistem adalah kegiatan merancang sistem secara rinci berdasarkan hasil analisa sistem yang ada, sehingga menghasilkan model sistem baru yang akan diusulkan dan juga disertai dengan rancangan database dan spesifikasi program. Alat bantu yang digunakan pada penelitian ini dalam merancang sistem adalah:

\section{a. ERD (Entity Relationship Diagram)}

Digunakan untuk menggambarkan hubungan antara data store yang ada dalam diagram arus data.

b. LRS (Logical Record Structure)

Logical Record Structure berasal dari setiap entity yang diubah kedalam bentuk sebuah kotak dengan nama entity berada diluar kotak dan atribut berada diluar kotak.

c. Conceptual Data Model

Conceptual Data Model menunjukkan konsep-konsep, penggabungan antara konsep-konsep dan atribut-atribut dari sebuah model data.

d. Relasi

Relasi digunakan untuk mendefinisikan dan mengilustrasikan model conceptual secara terperinci dengan adanya primary key dan foreign key.

e. Spesifikasi Basis Data

Spesifikasi Basis Data digunakan untuk menjelaskan tipe data yang ada pada model conceptual secara detail.

f. Normalisasi

Normalisasi adalah kegiatan mengelompokkan atribut-atribut sehingga mendapatkan bentuk yang normal. Untuk mengorganisasikan file dengan menghilangkan grup elemen yang berulang atau proses untuk menyederhanakan hubungan elemen data didalam tabel (record) dapat dilakukan dengan cara normalisasi.

g. Sequence Diagram

Menggambarkan interaksi antar obyek didalam dan sekitar sistem yang menekankan pada pesan apa yang disampaikan dan digambarkan dengan menekankan dimensi waktu atau peran masing-masingnya.

h. Class Diagram

Menggambarkan struktur dan deskripsi class, packege dan obyek beserta hubungan satu sama lain seperti containment, pewarisan, asosiasi dan sebagainya.

\section{HASIL DAN PEMBAHASAN Uraian Prosedur}


Kegiatan simpan pinjam yang berjalan pada Koperasi Simpan Pinjam SMPN 45 Jakarta adalah sebagai berikut:

\section{a. Pendaftaran Anggota}

Setiap guru atau pegawai SMP Negeri 45 Jakarta yang ingin menjadi anggota Koperasi Guru dan Pegawai SMP Negeri 45 Jakarta harus menyerahkan fotokopi KTP kepada bendahara, dan membayar simpanan pokok, simpanan wajib. Kemudian bendahara membuat Buku Simpanan dan mengarsip fotokopi KTP. Kemudian bendahara menyerahkan buku simpanan kepada anggota

b. Simpanan Anggota

Setiap bulan anggota membayar simpanan wajib dengan membawa buku simpanan, uang dan mengisi Bukti Setoran (BS), kemudian bendahara mencatat ke dalam buku simpanan dan diberikan ke Anggota, kemudian lembar Bukti Setoran (BS) disimpan kedalam arsip Koperasi. Jenis simpanan Koperasi SMP Negeri 45 Jakarta ada 3 yaitu:

1) Simpanan Pokok

Simpanan pokok dibayarkan satu kali pada saat anggota baru. Besarnya jumlah simpanan pokok sudah ditentukan oleh koperasi yaitu sebesar Rp 1.000.000,- (Satu Juta Rupiah)

2) Simpanan Wajib Pembayaran simpanan wajib dibayarkan setiap sebesar Rp 50.000,(Lima Puluh Ribu Rupiah).

3) Simpanan Sukarela Pada Koperasi SMP Negeri 45 Jakarta besarnya simpanan sukarela ditetapkan nominalnya berdasarkan pengajuan dari anggotanya dan akan tetap nominalnya.

c. Pengajuan Pinjaman

Anggota yang ingin meminjam uang pada Koperasi harus membawa fotokopi KTP dan membawa buku simpanan serta mengisi Surat Permohonan Pinjaman (SPP). Kemudian diserahkan kepada bendahara dan ditinggalkan di Koperasi, bendahara melakukan konfirmasi kepada anggota melalui telepon.

Anggota yang masih memiliki pinjaman tidak diperkenankan mengajukan pinjaman lagi. Setiap kali peminjaman dibatasi maksimal $\mathrm{Rp}$ 10.000.000,- (Sepuluh Juta Rupah), pinjaman hanya boleh diangsur maksimal 10 (sepuluh) bulan dengan bunga $2 \%$ dari setiap pinjaman.

\section{d. Surat Pengakuan Hutang (SPH) dan}

Pencairan Dana

Bendahara menyerahkan SPP kepada ketua atau wakil Koperasi Guru dan Pegawai
SMP Negeri 45 Jakarta, jika memenuhi syarat maka ketua atau wakil Koperasi Guru dan Pegawai SMP Negeri 45 Jakarta menandatangani Surat Permohonan Pinjaman (SPP) sebagai persetujuan, setelah itu SPP tersebut diserahkan kepada bendahara untuk merealisasikan pinjaman tersebut, tetapi jika tidak memenuhi syarat maka SPP akan dikembalikan pada anggota yang bersangkutan. Kemudian bendahara membuat Surat Pengakuan Hutang (SPH) berdasarkan SPP. SPH yang sudah diisi diberikan kepada anggota untuk ditandatangani diatas materai. SPH yang sudah ditandatangani anggota di arsipkan bendahara. Setelah itu bendahara membuat kwitansi sebagai bukti pinjaman dan Buku Angsuran. Fotokopi kwitansi, uang dan buku angsuran diberikan ke anggota kwitansi asli diarsip oleh bendahara.

e. Pembayaran Angsuran

Anggota yang ingin membayar angsuran membawa Buku Angsuran (BA) serta uang angsuran kemudian mengisi form angsuran dan menyerahkan ke bendahara. bendahara mencatat angsuran yang dibayar kedalam BA, kemudian menyerahkan kembali Buku Angsuran (BA) kepada anggota kemudian form angsuran diarsip oleh staff simpan pinjam.

\section{Analisa Proses}

Berdasarkan uraian prosedur diatas, berikut ini adalah kegiatan-kegiatan yang dilakukan oleh Koperasi Guru dan Pegawai SMP Negeri 45 Jakarta dalam melaksanakan transaksitransaksi simpan pinjam, yang digambarkan pada Activity Diagram sebagai berikut :
a. Activity Diagram Proses Pendaftaran Anggota 


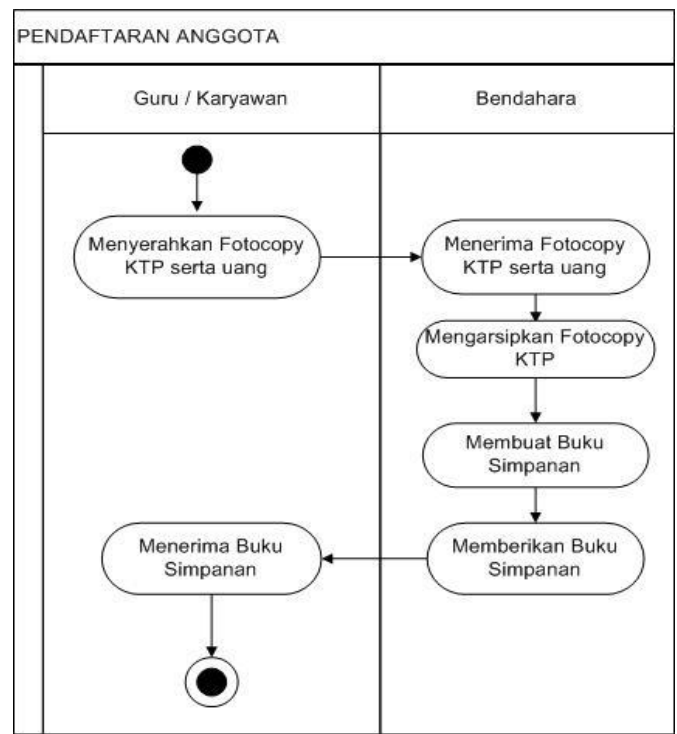

Gambar 1 Activity Diagram Proses Pendaftaran Anggota

b. Activity Diagram Proses Simpanan Anggota

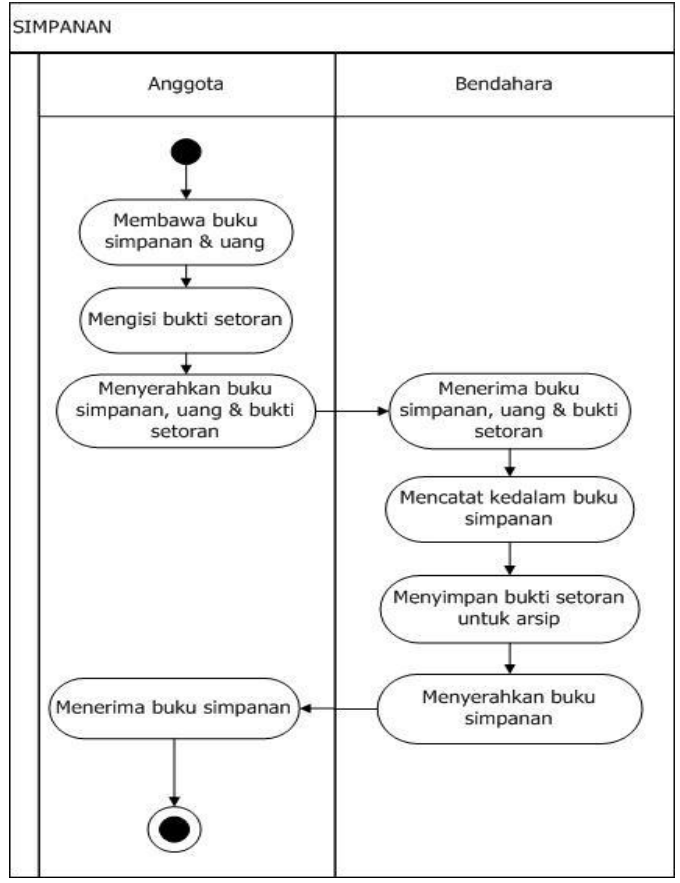

Gambar 2 Activity Diagram Proses Simpanan Anggota c. Activity Diagram Proses Pengajuan Pinjaman

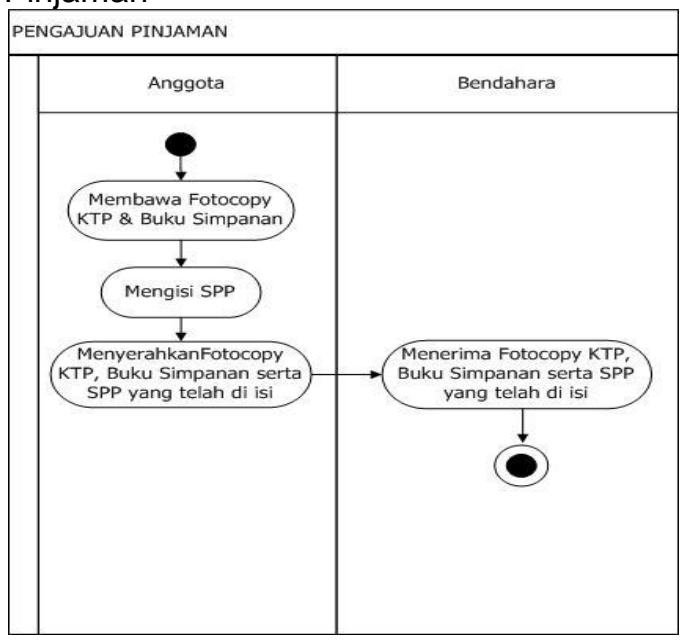

Gambar 3 Activity Diagram Proses Pengajuan Pinjaman

d. Activity Diagram Proses Surat Pengakuan Hutang (SPH) dan Pencairan Dana

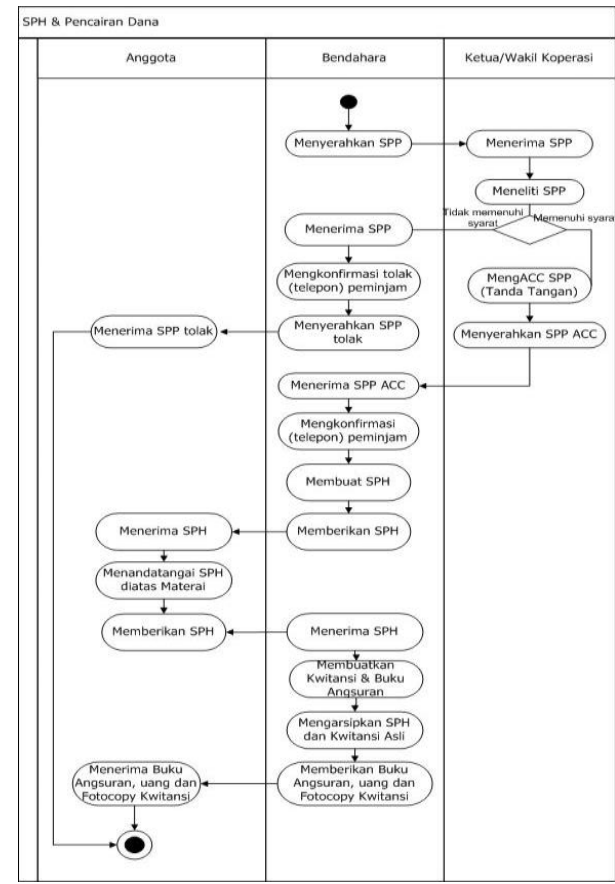

Gambar 4 Activity Diagram Proses SPH \& Pencairan Dana 
e. Activity Diagram Proses Pembayaran Angsuran

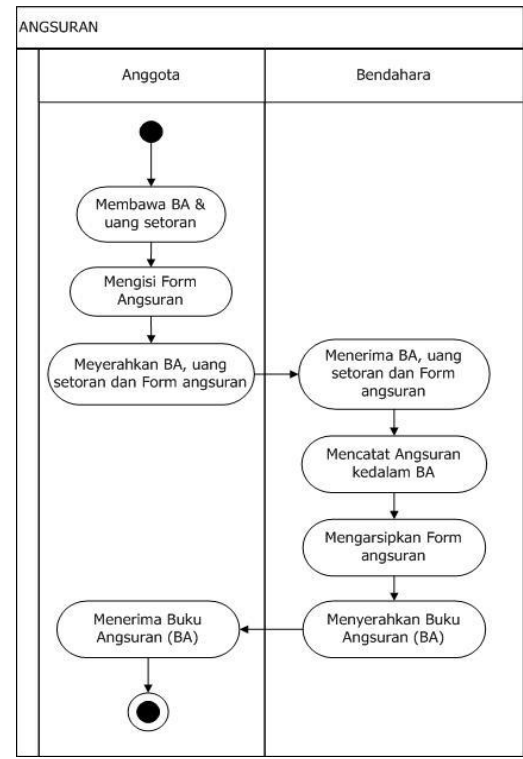

Gambar 5 Activity Diagram Proses Pembayaran Angsuran

\section{Use Case Diagram}

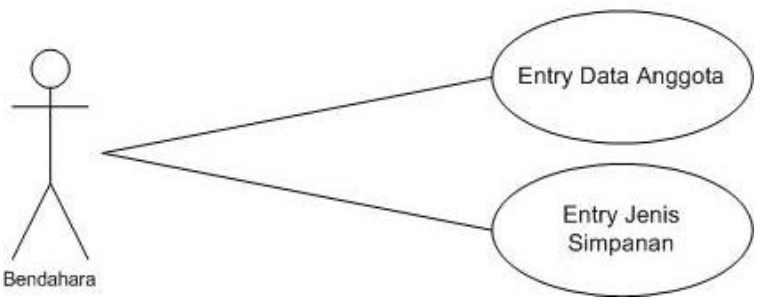

Gambar 6 Use Case Diagram File Master

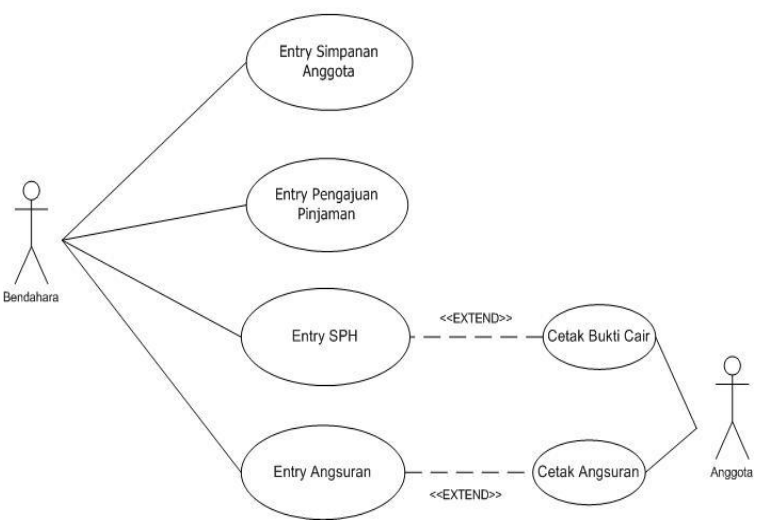

Gambar 7 Use Case Diagram File Transaksi

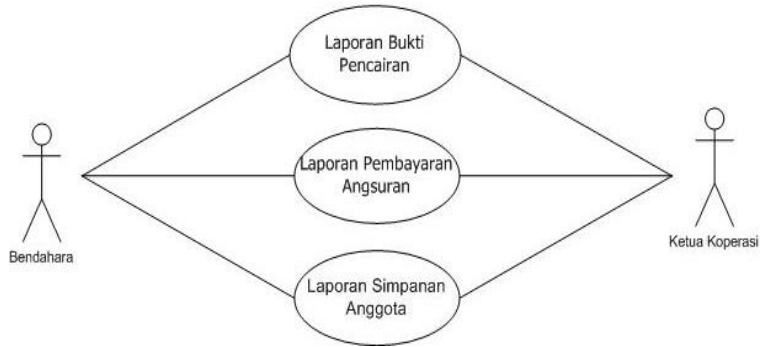

Gambar 8 Use Case Diagram Laporan

Entity Relationship Diagram (ERD) atau Diagram-ER

Entity Relationship Diagram (ERD) atau Diagram-ER adalah suatu model teknik pendekatan yang menyatakan atau menggambarkan hubungan suatu model. Didalam hubungan ini tersebut dinyatakan utama dari penggambaran Diagram-ER adalah menunjukan objek data (entity) dan hubungan (relationship), yang ada pada entity berikutnya.

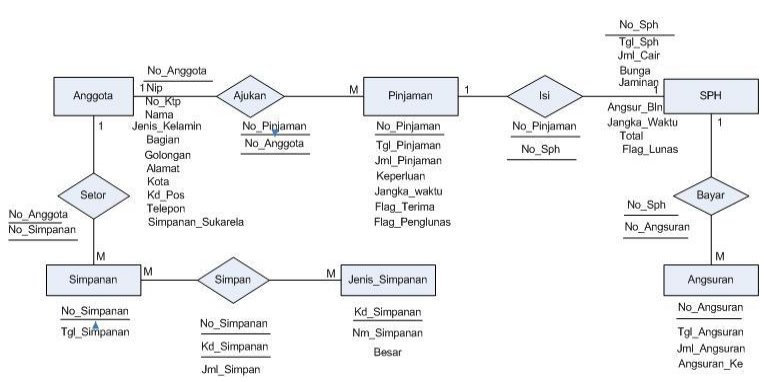

Gambar 9 Entity-Relationship Diagram

\section{Rancangan Layar}

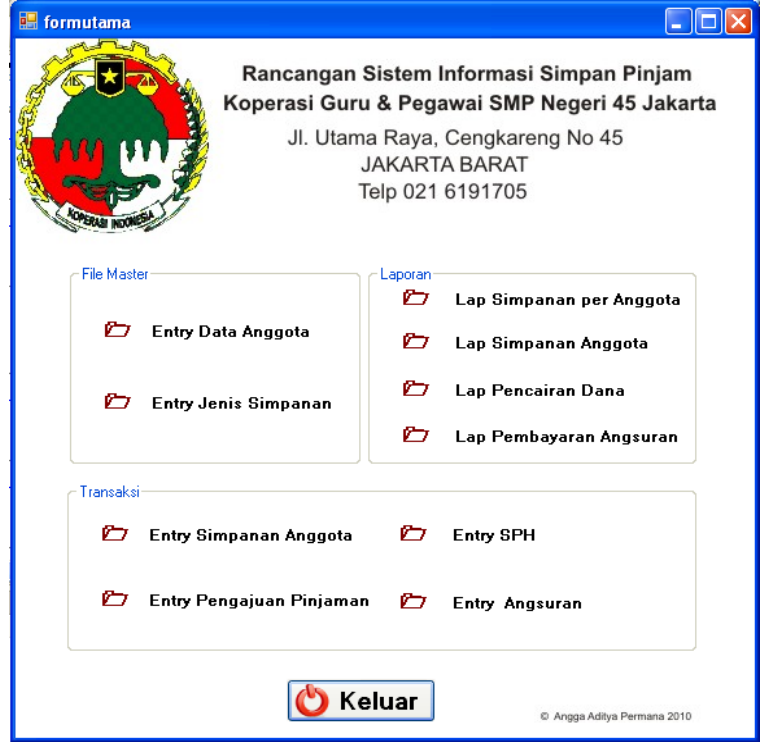


Gambar 10 Rancangan Layar Menu Utama

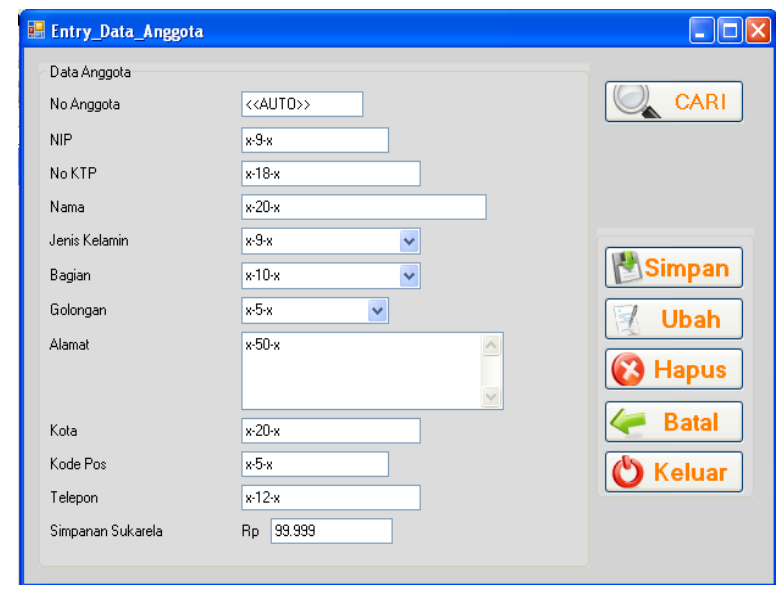

Gambar 11 Rancangan Layar Entry Data Anggota

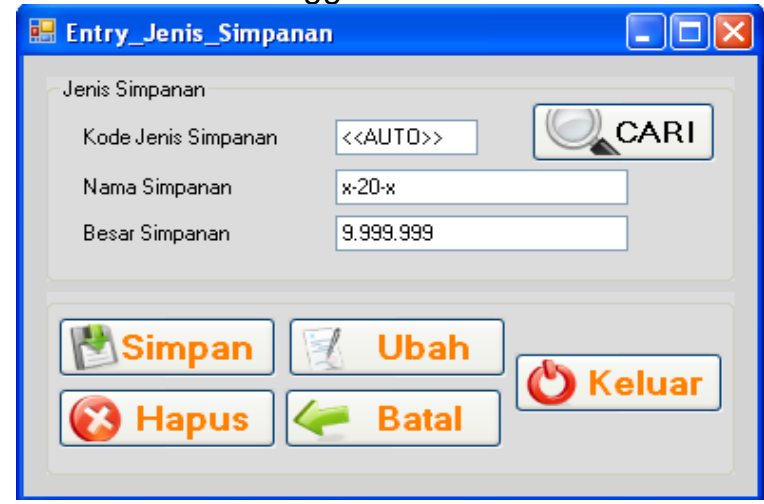

Gambar 12 Rancangan Layar Entry Jenis Simpanan

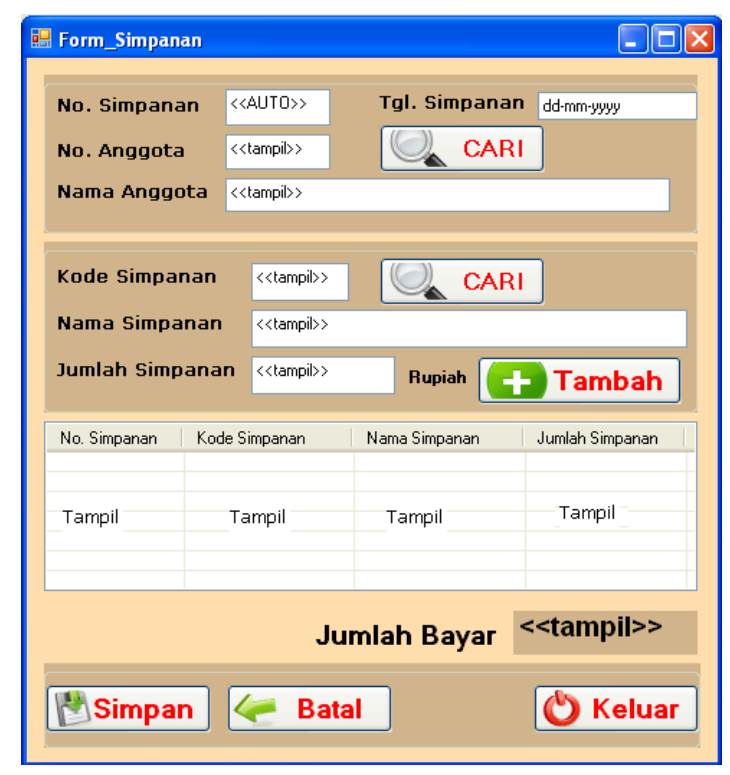

Gambar 13 Rancangan Layar Entry Simpanan Anggota

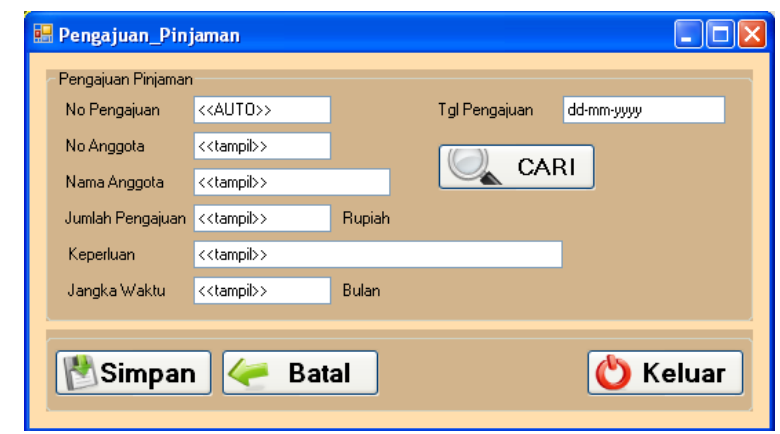

Gambar 14 Rancangan Layar Entry Pengajuan Pinjaman

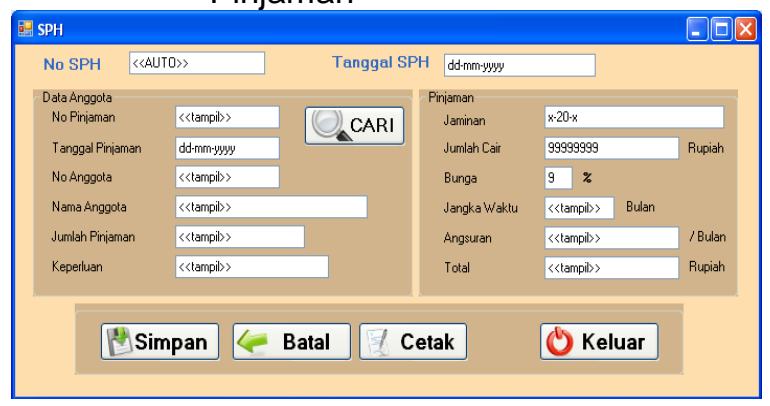

Gambar 15 Rancangan Layar Entry SPH

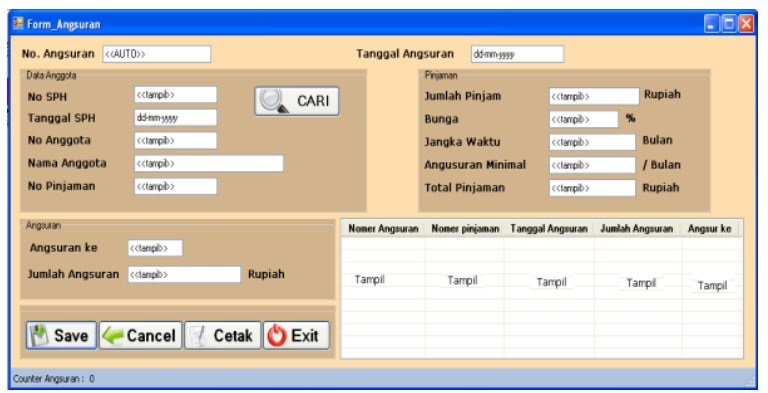

Gambar 16 Rancangan Layar Entry Angsuran

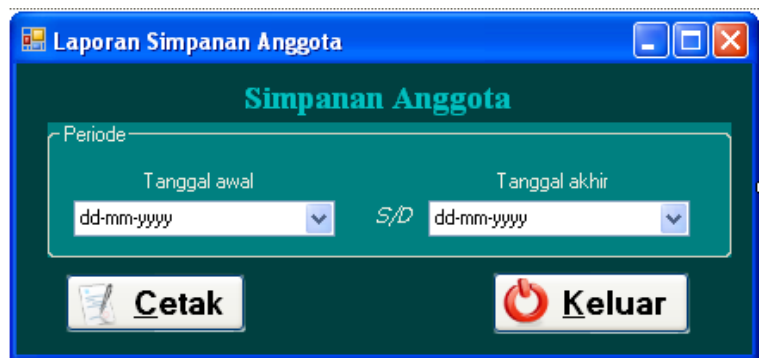

$\begin{array}{ccc}\text { Gambar } 17 \quad \begin{array}{c}\text { Rancangan } \\ \text { Simpanan } \\ \text { Periode }\end{array} & \begin{array}{c}\text { Layar Laporan } \\ \text { Anggota per }\end{array} \\ & & \end{array}$ 


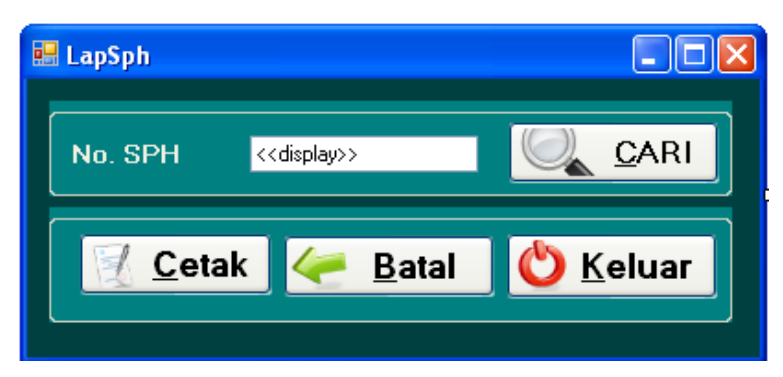

Gambar 18 Rancangan Layar Laporan Cetak $\mathrm{SPH}$

\section{KESIMPULAN}

Sistem informasi ini dapat memberikan pengetahuan mengenai data-data yang dibutuhkan dengan akurat sehingga membantu dalam melakukan pengontrolan, mengurangi kesalahan pencatatan dan perhitungan yang sering dilakukan oleh manusia ( human error), proses simpan pinjam dapat dilakukan dengan cepat dan tidak perlu lagi dilakukan secara manual, keamanan data akan lebih terjamin dan juga mempermudah dalam pencarian data serta mempercepat pengolahan data dan pembuatan laporan serta informasi yang dihasilkan lebih akurat, cepat dan lengkap.

\section{REFERENSI}

[1] Sutabri T. 2012. Analisis Sistem Informasi. Yogyakarta: Andi Offset.

[2] Tim Penyusun Kamus Pusat Pembinaan dan Pengembangan Bahasa. 1991. Kamus Besar Bahasa Indonesia. Jakarta: Balai Pustaka.

[3] Jogiyanto HM. 2002. Analisis dan Disain Sistem Informasi : Pendekatan Terstruktur Teori dan Praktek Aplikasi Bisnis. Yogyakarta: Andi Offset.

[4] Cook BG. 1977. Land resources information systems: use and display. Dalam :A.W Moore \& S.W Bie (eds.).Uses of soil information systems. Wagenigen: Center for agric. Publ. and documentation .
[5] Munir R. 2011. Algoritma dan Pemrograman. Bandung: Informatika. 